\title{
BIBLIOTERAPI KAEDAH DIDIK HIBUR MEMOTIVASIKAN KANAK-KANAK SEKOLAH DALAM HOSPITAL
}

\author{
Bibliotherapy with Fun Learning Methods Motivate School Kids in Hospital
}

\author{
Ani Omar \\ Fakulti Bahasa dan Komunikasi, \\ Universiti Pendidikan Sultan Idris, Tanjong Malim, Perak, Malaysia \\ ani.omar@fbk.upsi.edu.my
}

\begin{abstract}
ABSTRAK
Kajian ini bertujuan untuk mengenal pasti keberkesanan bahan sastera yang boleh dijadikan sebagai terapi untuk murid-murid sekolah dalam hospital (SDH). Kajian ini melibatkan sebuah SDH yang terpilih di semenanjung Malaysia. Bahan bacaan sastera yang digunakan dalam kajian ini meliputi lima buah buku cerita karya Khadijah Hashim yang berjudul Cerita Itik dan Buaya, Semut Melancong ke Pulau Pinang, Angsa Berjasa, Ikan Emas Mangsa Banjir dan Sedap Rumput Enak Lagi Lobak. Biblioterapi kaedah didik hibur akan dijalankan menggunakan buku cerita yang berkenaan. Lima orang kanak-kanak terlibat dalam kajian ini berumur antara 5 hingga 6 tahun. Penyelidik juga menggunakan kaedah permerhatian, temu bual, dan kajian kepustakaan. Nama hospital, identiti murid-murid yang terlibat serta guru dan lain-lain yang berkaitan dengannya tidak dinyatakan kerana ia berkaitan dengan etika yang perlu dipatuhi. Begitu juga dengan bahan bukti seperti video atau gambar tidak dapat disertakan dalam artikel ini kerana mematuhi prosedur yang telah ditetapkan. Sehubungan dengan itu bahan bacaan karya sastera yang digunakan secara biblioterapi untuk kanak-kanak sekolah dalam hospital bertujuan memotivasikan mereka supaya terus berminat dalam pelajaran walaupun dalam masa yang sama mereka sedang dirawat. Bersesuaian dengan keadaan mereka yang sedang sakit dalam masa yang sama ingin belajar kaedah didik hibur diaplikasikan supaya kesannya sebagai terapi lebih memuaskan. Kajian mendapati penerapan nilai-nilai positif melalui karya sastera mampu mendorong kanak-kanak SDH untuk membaca dan menghayatinya selain memberi kesan yang baik dari aspek perkembangan bahasa dan komunikasi, kognitif serta personaliti. Selain daripada itu biblioterapi kaedah didik hibur dapat membantu kanak-kanak untuk menerima kenyataan dan meningkatkan pencapaian akademik mereka. Implikasi daripada kajian ini mendapati bahawa penghasilan karya sastera kanak-kanak yang berkualiti dan menarik bukan sahaja dapat memberikan kesan positif malah dapat bertindak sebagai terapi kepada kanak-kanak SDH.
\end{abstract}

Kata Kunci: Biblioterapi, Bahan Sastera, Motivasi, Sekolah dalam Hospital

\begin{abstract}
The purpose of this study is to identify the effectiveness of literary materials that can be used as therapy for school children in hospitals (SDH). This study involved a selected SDH in peninsular Malaysia. Literary literary materials used in this study include the five books of Khadijah Hashim's story entitled Duck and Crocodile Story, Travel Ants to Penang, Angsa Berjasa, Flood Victim Gold and Sweet Grass Enak Lagi Lobak. Bibliotherapist will learn how to use the story books. Five children involved in the study were between 5 and 6 years old. The researchers also used the methods of observation, interviews, and literature studies. The name of the hospital, the identities of the students involved and teachers and others associated with it are not stated as it relates to the ethics that must be followed. Similarly, evidence such as video or pictures can not be included in this article because it complies with the prescribed procedure. In this regard, literary literary materials used for bibliotherapy for school children in SDH hospitals are intended to motivate them to continue to be interested in their studies even though they are being treated. In line with the condition of those who are sick at the same time wanting to learn how to learn the comfort of their application so that their effects as therapy are more satisfying. Studies have shown that the application of positive values through literary works can encourage SDH children to read and appreciate it as well as giving a good impact on language and communication, cognitive and personality development. In addition, bibliotherapy is a means of encouraging children to accept statements and improve their academic achievement.
\end{abstract}


The implication of this study found that the creation of quality and interesting children's literary works not only contributed positively but also acted as a therapy to SDH children.

Keywords: Bibliotherapy, Literary Materials, Motivation, School in Hospital

\section{PENGENALAN}

Makalah ini adalah hasil penyelidikan geran penyelidikan Fundamental (FRGS). Penyelidik merakamkan penghargaan kepada Kementerian Pengajian Tinggi Malaysia di atas pengurniaan geran ini. Penyelidikan ini ada kaitannya dengan kanak-kanak yang sedang belajar di Sekolah Dalam Hospital (SDH). Sastera merupakan satu bidang seni kreatif bertunjangkan bahasa yang indah dan mampu mempengaruhi individu yang memahaminya. Menurut Hashim Awang (2015), sastera merupakan hasil seni daripada ciptaan pengarang yang mempunyai perasaan, pemikiran, sikap, dan ideologi tertentu. Tambah beliau, sastera tidak tercipta begitu sahaja melainkan dengan maksud-maksud tertentu yang selalunya untuk kebaikan manusia. Sehubungan dengan itu tidak keterlaluan jika dikatakan kehebatan sastera mampu mempengaruhi pemikiran dan jiwa manusia khususnya kearah kebaikan. Oleh yang demikian adalah disarankan elemen sastera sebaiknya diterapkan di jiwa kanak-kanak pada awal usia semasa masih diperingkat 'rebung' lagi. Menurut Halimah Mohamed dan Mohamad Luthfi (2013), cerita-cerita dalam sastera kanak-kanak bukan hanya menyampaikan cerita-cerita yang mencabar akal kanak-kanak, tetapi juga menciptakan makna-makna bagi kanak-kanak yang membacanya. Menurut Ani Haji Omar (2014), sastera kanak-kanak adalah berbeza daripada sastera dewasa, di mana tujuan menulisnya adalah untuk memberikan tauladan yang baik, di samping memberikan hiburan. Penerapan nilai-nilai positif di awal usia melalui sastera kanakkanak yang menyeronokkan mampu mendorong mereka untuk membaca dan hal ini boleh memberi kesan dari aspek perkembangan bahasa dan komunikasi, kognitif dan personaliti kanak-kanak. Selain penghasilan karya sastera kanak-kanak yang berkualiti dan menarik, teknik penyampaiannya juga perlulah menyeronokan dan bersesuaian dengan umur kanakkanak. Salah satu teknik atau pendekatan yang boleh digunakan untuk mengajar kanak-kanak mengenai sastera ialah teknik didik hibur.

Didik hibur adalah satu pendekatan pengajaran yang mampu memberi keseronokan kepada murid-murid dan dalam masa yang sama tidak mengabaikan objektif pengajaran dan pembelajaran yang telah ditetapkan. Secara dasarnya, didik hibur bermaksud mendidik sambil menghibur dan pendekatan pengajaran ini telah diperkenalkan oleh kerajaan melalui Kurikulum Bersepadu Sekolah Rendah (KBSR) yang telah mula dilaksanakan pada tahun 2010. Pendekatan didik hibur dan apresiasi bahasa merupakan salah satu langkah oleh Kementerian Pendidikan untuk memperkukuhkan kemahiran asas Bahasa Melayu dalam kalangan murid. Hal ini dipersetujui oleh Amir Juhari dan Noor Zila (2012) yang mengatakan bahawa pembelajaran secara didik hibur mampu mencungkil potensi murid untuk menerokai pelbagai bidang ilmu pengetahuan.

Gabungan yang harmoni antara sastera kanak-kanak dan kaedah pengajaran didik hibur bukan sahaja dapat memberikan murid nasihat, pedoman, dan ilmu daripada karya sastera malah murid-murid akan turut terhibur dalam sesi pembelajaran tersebut. Sehubungan dengan itu kajian ini dijalankan untuk melihat keberkesanan sastera kanak-kanak dan kaedah didik hibur sebagai terapi kepada murid-murid sekolah dalam hospital (SDH) yang dimaklumi mempunyai masalah kesihatan dan sedang dirawat di hospital. Menurut Djohan (2006), terapi dilakukan untuk memperbaiki kekurangan yang terdapat pada rawatan perubatan seperti 
meningkatkan potensi, menyelesaikan masalah fizikal, emosi, dan masalah psikologi. Terapi dalam konteks ini merujuk kepada penyembuhan atau pemulihan bagi aspek emosi dan psikologi murid. SDH adalah satu konsep di mana sekolah dibawa ke wad Pediatrik (kanakkanak) bagi membolehkan pesakit kanak-kanak meneruskan pembelajaran dan mengelakan mereka dari tercicir dalam pelajaran. Setakat ini, terdapat 15 buah SDH di Malaysia menawarkan pembelajaran secara percuma dan secara tidak langsung hak pesakit kanak-kanak untuk mendapatkan pendidikan terjamin. Perkara ini adalah selaras dengan Artikel 28 dan 29 Konvensyen Mengenai Hak Kanak-Kanak, Pertubuhan Bangsa-Bangsa Bersatu (PBB) yang memberi penekanan kepada hak kanak-kanak mendapatkan pendidikan dan penekanan terhadap kualiti dan kandungan pendidikan tersebut.

Terapi biblio atau lebih dikenali sebagai biblioterapi adalah merujuk kepada bimbingan melalui pembacaan. Mengikut pendapat Noraida Hassan (2013) beliau menyatakan penggunaan buku atau bahan bacaan yang bersesuaian mengikut peringkat umur dan keperluan dapat membantu bagi menyelesaikan masalah dan memberikan rawatan khusus buat kanakkanak yang perlu dibimbing melalui pembacaan. Terapi biblio juga dikenali sebagai terapi buku dan boleh digunakan oleh semua lapisan masyarakat. Dalam konteks pendidikan, terapi biblio dapat meningkatkan motivasi instrinsik kanak-kanak terhadap sesuatu mata pelajaran. Penggunaan terapi biblio boleh digunakan untuk murid-murid sekolah dalam hospital (SDH) yang sedang dirawat kerana menghidapi pelbagai masalah kesihatan dalam masa yang sama tidak mahu ketinggalan dalam pelajaran. Sehubungan dengan itu objektif pengajaran terapi biblio adalah untuk membantu kanak-kanak bagi mengurangkan tekanan yang dihadapi. Pembacaan juga adalah salah satu rawatan untuk pesakit yang menghidapi penyakit murung kerana berkemungkinan mempunyai sejarah atau pengalaman yang pernah dilalui sebelum ini seperti trauma dan gangguan emosi yang perlu dipulihkan. Proses membaca adalah terapi yang boleh membantu menghilangkan kebosanan contohnya semasa menjalani proses rawatan yang mengambil masa lama bagi sesuatu jenis penyakit yang dihidapi oleh murid-murid di SDH seperti penyakit buah pinggang dan kanser. Terapi biblio juga digunakan untuk pesakit dalam kalangan kanak-kanak yang menghadapi masalah ketegangan seperti panas baran, marah dan kurang sabar dalam menghadapi sesuatu situasi yang tidak menyenangkan. Terapi biblio dapat meningkatkan perkembangan kanak-kanak SDH dan boleh membantu menyelesaikan masalah dari aspek psikologi dalam masa yang sama memperoleh beberapa ilmu dan kemahiran berbahasa.

\section{PENYATAAN MASALAH}

Kajian awal mendapati penggunaan bahan sastera di SDH adalah dalam projek NILAM iaitu untuk menggalakkan murid-murid membaca. Manakala kaedah pengajaran didik hibur dilaksanakan tetapi lebih tertumpu kepada subjek Bahasa Melayu, Bahasa Inggeris, Sains dan Matematik. Terdapat beberapa faktor yang menyebabkan kurangnya kajian berkaitan dengan kanak-kanak SDH. Antaranya ialah tiada NGO atau badan-badan yang bertanggungjawab mahu menjalankan penyelidikan berkaitan dengan SDH. Hal ini mungkin disebabkan oleh bilangan SDH yang sedikit iaitu hanya 15 buah sekolah di dalam negara berbanding dengan sekolah-sekolah yang lain yang jauh lebih banyak jumlahnya. Bilangan sekolah yang sedikit ini menyebabkan SDH berada pada kedudukan minoriti dan menyebabkan penyelidikpenyelidik lain tidak berminat menjalankan kajian kerana impak kajian mungkin tidak seberapa. Selain itu, mungkin masih ramai penyelidik atau rakyat Malaysia yang tidak menyedari akan kewujudan SDH yang telah bertapak sejak tahun 2011. Selain itu, kesukaran 
untuk memohon kebenaran masuk ke dalam kawasan hospital dan SDH bagi tujuan menjalankan penyelidikan menyebabkan kurang kajian khusus dilakukan terutama kajian yang mengaplikasi bahan sastera sebagai terapi. Sehubungan dengan itu kajian ini dijalankan adalah untuk mengisi lompang yang dinyatakan dan akan melihat sejauh mana keberkesanan bahan sastera sebagai terapi atau biblioterapi kaedah didik hibur untuk murid-murid SDH.

\section{KEPENTINGAN KAJIAN}

Kajian ini penting khususnya untuk meningkatkan kualiti pengajaran dan pembelajaran di Sekolah Dalam Hospital (SDH). Disebabkan tiada research and development (R\&D) dilakukan terhadap SDH khususnya yang mengaitkan penggunaan bahan sastera untuk kanak-kanak SDH maka kajian ini harus dijalankan sebagai sumbangan kepada guru-guru SDH yang mengajar subjek Bahasa Melayu dengan pengaplikasian bahan sastera sebagai terapi. Penyelidikan mengenai penggunaan bahan sastera khususnya buku-buku cerita kaedah didik hibur sebagai terapi atau biblioterapi untuk SDH membolehkan guru-guru mengetahui kehendak kanakkanak dan kaedah pengajaran dan pembelajaran yang terbaik bagi kanak-kanak di SDH. Hasil kajian ini diharap akan menggalakkan penghasilan karya sastera khususnya untuk kanak-kanak yang berkualiti disebabkan oleh kesan positif yang boleh diberikan kepada murid-murid. Selain itu, kajian ini juga boleh mendedahkan kepada orang ramai mengenai sastera terapi iaitu penggunaan bahan sastera sebagai terapi atau kaedah biblioterapi untuk membantu kanakkanak yang sedang dirawat di hospital bagi mengurangkan dengan cara didik hibur.

\section{BATASAN KAJIAN}

Kajian yang dijalankan adalah melibatkan Sekolah Dalam Hospital (SDH) yang terpilih sahaja di semenanjung Malaysia. Bahan bacaan sastera yang digunakan dalam kajian ini meliputi lima buah buku cerita karya Khadijah Hashim yang berjudul Cerita Itik dan Buaya, Semut Melancong ke Pulau Pinang, Angsa Berjasa, Ikan Emas Mangsa Banjir dan Sedap Rumput Enak Lagi Lobak. Lima orang kanak-kanak terlibat dalam kajian ini berumur antara 5 hingga 6 tahun sahaja yang belajar di SDH terpilih.

\section{METODOLOGI}

Kajian ini berbentuk kualitatif dengan mengaplikasi lima buah buku cerita seperti yang telah dinyatakan dalam batasan kajian. Biblioterapi kaedah didik hibur akan dijalankan menggunakan buku cerita yang berkenaan. Penyelidik juga menggunakan kaedah permerhatian, temu bual, dan kajian kepustakaan. Lima orang murid yang terlibat dalam kajian ini di SDH yang terpilih. Temubual semi struktur dijalankan kepada guru yang mengajar di sekolah yang berkenaan. Nama hospital, identiti murid-murid yang terlibat serta guru dan lainlain yang berkaitan dengannya tidak dinyatakan kerana ia berkaitan dengan etika yang perlu dipatuhi. Keberkesanan kaedah pengunaan bahan sastera secara biblioterapi akan dinyatakan dalam dapatan kajian selanjutnya.

\section{Konsep Biblioterapi}

Konsep yang digunakan dalam terapi biblio ialah terapi membaca untuk mendapatkan pengalaman dan rawatan. Terapi biblio merangkumi pelbagai pemilihan bahan membaca untuk 
individu yang mempunyai pengalaman yang benar dan relevan dengan situasi yang tertulis di dalamnya. Terapi biblio merangkumi pendekatan terapi bercerita dan telah diluaskan hingga dipadankan dengan aktiviti perbincangan mahupun bermain. Terapi bercerita merupakan satu terapi yang menyampaikan peranan teraputik yang terkandung dalam sesuatu cerita. Ia diolah dan berpotensi untuk menimbulkan sikap positif dalam diri, membangkitkan emosi, merangsang imaginasi, mencetuskan inspirasi serta menambah kemahiran berfikir. Terapi bercerita ini boleh digunakan bagi proses terapi bersama kanak-kanak SDH untuk menarik minat mereka dalam melahirkan perasaan dan emosi diri. Antara kebaikan terapi bercerita ini adalah ia dapat merangsang pemikiran individu, merupakan salah satu medium untuk mereka bertukar fikiran dan mengembangkan idea kritis, meningkatkan keyakinan diri serta meningkatkan keupayaan berfikir walaupun dalam masa yang sama mereka sakit dan masih menerima rawatan di hospital.

\section{Tujuan Biblioterapi}

Kaedah terapi biblio yang digunakan adalah penting kerana ia melibatkan penggunaan bahanbahan bacaan untuk membantu individu menyelesaikan masalah. Pada awalnya terapi biblio digunakan oleh guru kaunseling untuk kanak-kanak yang menghidapi masalah seperti murung, trauma dan mengalami masalah marah yang sukar untuk dikawal. Menurut pendapat Sohaimi Abdul Aziz (1998), emosi kanak-kanak pada peringkat prasekolah mula berada pada peringkat yang lebih matang khususnya di dalam konteks emosi sosial. Pada waktu ini, mereka mengalami pelbagai perasaan tentang emosi seperti perasaan tidak selamat, cemburu, dihina, bangga dan yakin. Kepentingan biblioterapi kepada guru SDH adalah untuk membantu kanakkanak yang mengalami masalah dari aspek psikologi ini dan boleh mengesan permasalahan dalam pembelajaran mereka. Sehubungan dengan itu tidak keterlaluan jika dikatakan proses terapi biblio menggunakan bahan sastera mampu mengenalpasti masalah kanak-kanak secara psikologi supaya mereka tidak berputus asa dalam menerima rawatan di hospital dan dalam masa yang sama mahu mengikuti pengajaran dan pembelajaran di SDH.

\section{DAPATAN KAJIAN}

Kajian mendapati kelima-lima buah buku cerita yang diaplikasi mempunyai unsur terapi serta dapat memberi motivasi kepada kanak-kanak SDH. Seperti cerita Itik dan Buaya, permulaan cerita mengisahkan kehidupan sepasang itik dengan lima ekor anaknya. Mereka berjiran dengan sepasang ayam juga dengan dua ekor anaknya. Keseluruhan cerita ini memaparkan bagaimana habitat itik yang sukakan air, pandai berenang, tidak takut hujan dan suka bermain dalam lopak-lopak air. Berbeza dengan habitat ayam yang takutkan air dan tidak pandai berenang. Kanak-kanak yang membaca buku cerita ini akan mengetahui perbezaan antara ayam dan itik. Klimaks cerita ini berlaku apabila anak-anak itik yang berenang bersama ibu bapa mereka terpisah di sungai dan telah dibawa arus deras hingga ke muara sungai. Pengakhiran cerita anak-anak itik telah diselamatkan oleh sang buaya yang baik hati walaupun selama ini haiwan ini dikategorikan sebagai haiwan yang ganas.

Cerita Semut Melancong ke Pulau Pinang pula mengisahkan bagaimana kegigihan sekumpulan semut mencari makanan, berkongsi rezeki yang mereka dapat dan sifat kerajinan, ketekunan dan setia kawan dalam kalangan mereka. Cerita ini ditambah lagi dengan pertolongan seekor ular lidi membantu kumpulan semut ini memanjat pokok untuk memakan buah jambu. Selanjutnya diceritakan pula bagaimana seekor semut dapat mengikut tuannya ke 
Pulau Pinang tanpa disedari oleh tuannya. Semut menceritakan keindahan tempat-tempat yang dilawati oleh tuannya. Moral daripada cerita ini adalah tidak ada yang mustahil akan berlaku jika takdirnya diizinkan oleh Yang Maha Pencipta. Begitulah juga sebagai satu terapi melalui buku cerita untuk murid-murid SDH. Mereka juga boleh sembuh dengan izin-Nya.

\section{Mengurangkan Rasa Resah dan Gelisah}

Penggunaan biblioterapi menggunakan bahan sastera iaitu lima buah buku cerita tersebut dapat mengurangkan rasa resah dan gelisah dalam kalangan kanak-kanak SDH. Mereka akan rasa gembira da terhibur apabila guru dapat membawa pendekatan secara didik hibur menggunakan buku cerita berkenaan. Melalui pembacaan, buku cerita yang bersesuaian juga menyokong perkembangan tingkah laku kanak-kanak iaitu dari segi menanamkan minat membaca dalam diri mereka. Apabila kanak-kanak membaca, mereka juga dapat menzahirkan perasaan dan luahan dari hati mereka. Terdapat pelbagai kaedah, pendekatan serta bahan bantu mengajar yang dapat digunakan oleh guru untuk mengajar kemahiran membaca tahap awal. Umpamanya melalui pelbagai bahan media elektronik seperti e-book, di samping aktiviti kesenian, nyanyian, lakonan, seni arogami dan sebagainya. Semua aktiviti ini bersumberkan bahan bacaan sastera yang dibawa oleh para guru untuk kanak-kanak SDH.

\section{Menyokong Perkembangan Moral}

Perkembangan moral yang dimaksudkan ialah perubahan dan peningkatan tahap kesedaran moral, peraturan, nilai dan norma yang telah ditetapkan dan dikongsi bersama-sama dalam masyarakat. Guru haruslah menerangkan tentang lebih lanjut lagi mengenai moral di dalam cerita seperti cerita Itik dan Buaya iaitu jalan cerita singkat tetapi penuh pengajaran dan bermakna jika disampaikan dengan penggunaan pendekatan yang berkesan kepada kanakkanak. Moral cerita ini ialah bagaimana ayah dan ibu sangat mengasihani anak-anaknya. Selain itu jangan kita mengutuk atau membenci seseorang yang dianggap musuh selama ini. Kerana tidak mustahil dia akan membantu kita suatu hari nanti. Dari segi lain, perkembangan moral merujuk kepada kebolehan untuk membezakan perkara betul atau salah. Kanak-kanak perlulah dibimbing untuk membezakan perkara yang baik mahupun yang tidak baik. Melalui pembacaan, kanak-kanak berpotensi meniru perlakuan watak juga cerita yang dibaca. Kanakkanak mudah tertarik dengan buku-buku yang dipilih mereka sendiri seperti lebih tertarik jika buku cerita itu mempunyai gambar atau ilustrasi yang menarik hati mereka. Menurut kajian Lee, Rosenfeld, Mendenhall, Rivers dan Tynes (2004), cerita sering menjadi kaedah pilihan untuk membentuk kesinambungan komunikasi budaya dalam aspek hubungan kekeluargaan, persahabatan dan kejiranan.

\section{Memupuk Nilai Membaca}

Menurut Affizal Ahmad (2015), membaca buku cerita dalam kalangan kanak-kanak mampu meningkatkan perbendaharaan kata, perkembangan literasi dan kemahiran bercerita dalam kalangan pembaca muda ini. Apabila timbulnya keseronokan membaca buku cerita menerbitkan rasa cinta kanak-kanak kepada buku, menggalakkan mereka untuk terus membaca dan mencintai ilmu sepanjang hayat mereka. Penggunaan medium pelbagai seperti gambar yang berwarna-warni di dalam buku cerita kanak-kanak sebagai terapi juga mampu menceriakan kanak-kanak. Dalam pemilihan buku cerita sebagai terapi biblio adalah sedikit sebanyak mempengaruhi perkembangan sosioemosi kanak-kanak. Antara contoh dan panduan yang boleh digunakan mencari buku yang berkaitan dengan minat kanak-kanak untuk membaca. Kanak-kanak akan lebih berminat jika bahan bacaan yang dipilih akan menarik 
minat dan akan menggemari buku yang dipilih oleh mereka sendiri. Menceritakan situasi dan memahamkan jalan cerita supaya guru boleh membina kebolehan kanak-kanak untuk membina emosi yang positif. Perkara ini boleh dikaitkan dengan jalan cerita Ikan Emas Mangsa Banjir. Murid-murid SDH akan tertarik hati untuk mengikuti seterusnya apakah yang terjadi kepada watak ikan emas yang telah terlepas dari akuarium tuannya akibat banjir melanda. Di akhir cerita ikan emas telah dapat menyesuaikan diri dengan ikan-ikan yang lain di dalam sungai. Perkara ini dapat memupuk emosi positif dalam kalangan kanak-kanak SDH, kerana walaupun mereka terasing dari rakan-rakan sekolah yang lain, tetapi di SDH mereka tetap dapat belajar dan sangat di sayangi oleh para guru, doktor yang merawat dan kakitangan hospital yang lain. Perkara ini jelas daripada pemerhatian dan temubual pengkaji dengan para guru di SDH yang dikaji.

\section{Menggalakkan Interaksi Kanak-kanak SDH}

Komunikasi juga amatlah penting kerana ia menggalakkan kanak-kanak untuk memberi pendapat dan membolehkan para guru dan kanak-kanak berinteraksi antara satu sama lain. Sebagai contoh, apabila menjalankan terapi biblio bersama pesakit, komunikasi yang efektif juga diambil kira kerana keupayaan kanak-kanak melahirkan perasaan akan membantu mereka mengenal dan memahami emosi mereka sendiri sebelum mengenali emosi orang lain. Interaksi antara guru dan kanak-kanak haruslah kerap kerana ia juga mempengaruhi kesan kepada perkembangan bahasa mereka. Interaksi positif adalah berkaitan dengan perkembangan bahasa kanak-kanak supaya lebih puitis dan gramatis. Guru digalak menggunakan kepelbagaian perkataan dan ayat dalam aktiviti rutin bersama kanak-kanak yang dirawat supaya dapat meningkatkan lagi perbendaharaan kata mereka jika dirangsang setiap hari. Seperti cerita Angsa Berjasa. Cerita ini mengisahkan pelbagai jenis unggas, seperti burung Raja Udang, burung Unta, burung Belatuk, burung Kasawari, burung Kelicap, burung Merak dan burung Penguin. Disamping diperkenalkan juga dengan ayam Belanda, angsa dan tupai. Kanak-kanak sudah tentu teruja untuk mengetahui setiap jenis unggas dan haiwan lain dalam cerita ini. Kerana mungkin ada yang belum pernah mereka kenali dan lihat di mana-mana.

\section{Mendengar Kata Ibu Bapa}

Pengajaran yang terdapat dalam cerita Sedap Rumput Enak Lagi Lobak adalah supaya kanakkanak mendengar kata ibu bapa. Jasa dan bakti ibu dan bapa tiada tandingan dan melalui cerita ini juga guru haruslah menerapkan pengajaran dan nilai-nilai positif terhadap kanak-kanak SDH supaya mereka sedar akan kasih sayang yang dicurahkan kepada mereka sejak kecil sehinggalah menjadi dewasa nanti. Apabila kasih sayang seorang ibu yang sanggup menjaga anaknya tanpa mengira masa, nilai menghormati dan membalas semula jasa amatlah penting. Terapi daripada cerita ini kanak-kanak SDH akan lebih bersemangat untuk cepat sembuh supaya sihat semula dan dapat belajar seperti sedia kala dan akhirnya dapat membalas jasa ibu dan bapa mereka suatu masa nanti.

\section{PERBINCANGAN}

\section{Menggalakkan Pembacaan Buku-buku Sastera}

Karya sastera ialah karya yang mempunyai daya kreatif yang asli dan tersendiri. Apabila merawat pesakit dengan kaedah terapi biblio, ia dapat memupuk mereka untuk membaca. Dengan menggalakkan pembacaan buku-buku sastera secara tidak langsung mereka akan lupa 
seketika kesakitan dan rawatan yang mereka sedang jalani. Kaedah biblioterapi juga akan memperkenalkan murid-murid SDH beberapa bentuk puisi tradisional seperti pantun dan lagulagu puisi yang terdapat dalam kelima-lima buku cerita ini. Contohnya dalam cerita Angsa Berjasa. Contoh pantunnya seperti berikut;

Terasa sejuk angin menderu,

Hujan senja orang berpayung;

Hati-hati jangan keliru,

Yang berjasa patut disanjung. (hlmn. 20)

Pantun juga terdapat dalam buku cerita Itik dan Buaya. Seperti contoh berikut;

Pucuk pauh pucuk mengkudu,

Tanam berbaris pokok pinang;

Kau jauh hati emak rindu,

Siang malam terkenang-kenang. (hlmn 17)

Lagu puisi juga diperkenalkan kepada murid-murid SDH yang terdapat dalam buku cerita ini seperti rangkap berikut;

Laju-laju rakitku laju

Lekas kita sampai ke hulu

Senang hatiku senang

Sungai tenang senang berenang. (hlmn 30)

Puisi dan lagu puisi ini akan menghiburkan kanak-kanak SDH di samping terus mendengar cerita yang disampaikan oleh para guru. Peranan seorang guru seterusnya haruslah menerapkan semangat dan memberi motivasi kepada kanak-kanak SDH untuk tidak berputus asa melawan penyakit yang dideritai di samping mendengar kata doktor dan pesan ibu bapa dan guru mereka.

\section{Merawat Pesakit Kaedah Biblioterapi atau Terapi Bacaan Khususnya Kanak-kanak SDH}

Kaedah terapi biblio atau terapi membaca sedikit sebanyak mengatasi masalah yang hidapi oleh kanak-kanak SDH seperti dapat meredakan rasa ketakuatan menerima rawatan di hospital. Bahan bacaan yang diberikan akan dapat mengurangkan kesakitan dan masalah emosi yang dilalui. Kehidupan yang bakal dilalui juga akan membawa perubahan dalam kehidupan mereka kelak. Watak dan penceritaan yang dipersembahkan juga dapat mempengaruhi perubahan sikap dan diri pesakit serta boleh membantu mengurangkan tekanan yang dihadapi. Aktiviti yang diadakan seperti terapi pembacaan bersama pesakit dan ibu bapa juga memberikan kesan dan impak yang sangat positif kepada pesakit dalam membina potensi diri dan membimbing pesakit terutamanya dalam membentuk kanak-kanak untuk masa depan yang akan mereka lalui dengan lebih baik lagi. Pesakit juga setiap kali akan berhadapan dengan pelbagai rawatan seperti terpaksa menerima rawatan untuk suntikan setiap hari,dan memakan ubat-ubatan yang diterima. Oleh itu, pesakit juga berasa terbeban dan tekanan yang dihadapi. Apabila mengadakan program terapi biblio untuk merawat pesakit, ia boleh membantu mereka mengurangkan kesakitan dan konflik diri yang mereka hidapi dan membantu menghiburkan hati mereka serta menceriakan mereka walaupun hanya seketika. 


\section{Meningkatkan Motivasi dan Psikologi Kanak-kanak SDH ke Arah Positif}

Tujuan terapi biblio juga adalah untuk memberikan sokongan moral untuk pesakit. Secara psikologinya, ia dapat memberikan motivasi untuk mereka bangkit semula apabila ditimpa sesuatu penyakit. Sokongan moral sangatlah penting dalam kehidupan seharian sesama manusia. Ini kerana apabila mengambil berat dan memberikan sokongan padu dapat mengembalikan semula semangat dan kekuatan untuk diri mereka. Kanak-kanak seharusnya diberikan galakkan dan peluang untuk mempelajari sesuatu yang baharu. Contohnya memberikan kebebasan kepada mereka untuk menjiwai watak dan perwatakan dalam cerita yang dibaca. Guru boleh membimbing kanak-kanak SDH untuk melakonkan watak-watak ini. Kaedah ini sedikit sebanyak dapat membantu mereka dalam proses pemulihan dan memberikan motivasi supaya pesakit menjadi lebih positif.

\section{Menyuburkan Daya Kreativiti dalam Kalangan Kanak-kanak SDH}

Amalan membaca ialah proses memperkayakan maklumat, memantapkan pemikiran dan mendewasakan tindakan sekaligus memupuk daya pemikiran yang kreatif dan inovatif. Ini kerana membudayakan pembacaan boleh memberikan ruang dan peluang untuk kanak-kanak menjana idea dan berimaginasi seketika bagi membolehkan kanak-kanak melukis, membuat origami di bawah bimbingan guru. Umpamanya melalui cerita Semut Melancong ke Pulau Pinang, kanak-kanak boleh membayangkan tempat-tempat menarik yang digambarkan dalam cerita berkenaan umpamanya menara KOMTAR, jambatan Pulau Pinang, Lapangan Terbang Bayan Lepas dan pelbagai destinasi menarik yang lain di Pulau Pinang. Peranan guru dan ibu bapa hendaklah sentiasa memberi galakkan dan sokongan kepada murid-murid ini supaya daya imaginasi mereka terus berkembang melalui pembacaan buku-buku cerita dan dapat dizahirkan melalui lukisan atau daya kreativiti yang lain.

\section{Kepentingan Biblioterapi Kepada Guru SDH Mengesan dan Membuat Pemerhatian Terhadap Kanak-kanak}

Kerjasama dan perbincangan bersama ibu bapa untuk mengesan dan membuat pemerhatian adalah penting kerana untuk mengesan perkembangan kanak-kanak. Penilaian juga adalah proses mendapat, menentukan dan memberi maklumat atau sumber yang berguna ataupun menganalisis hasil pengukuran bagi tindakan yang selanjutnya. Untuk proses pembelajaran, penilaian ialah proses mengumpul maklumat, membuat analisis dan keputusan iaitu perubahan tingkah laku dan perkembangan murid-murid. Penilaian juga dijalankan secara berterusan dan tidak formal bertujuan untuk memudahkan guru mengambil tindakan susulan. Oleh itu, para guru haruslah mengumpul maklumat mengenai perkembangan kanak-kanak selepas ataupun semasa melakukan aktiviti kumpulan atau individu. Guru juga merekodkan maklumat bagi tujuan yang sewajarnya. Ia juga bagi mengenal pasti pelbagai kecerdasan dan potensi bagi mempertingkat atau diberikan pengukuhan. Setiap penilaian yang direkod, guru haruslah melaporkan setiap perkembangan kanak-kanak kepada ibu bapa. Umpamanya bagi kanakkanak yang menghadapi kemurungan kesan daripada rawatan penyakit yang dideritai.

Daripada tidak mahu bercakap, berbual sehinggalah terdapat perubahan ketara kepada mereka dengan memberi tindak balas dan seterusnya dapat membaca, menghayati cerita dan mampu menjalankan aktiviti yang telah diatur oleh guru mereka. Perubahan positif ini akan mempengaruhi juga tahap kesihatan mereka dalam melawan penyakit. Inilah antara kesan positif yang dikatakan terapi melalui kaedah biblioterapi. 


\section{Membimbing dan Menyelesaikan Masalah Kanak-kanak Dengan Bahan Bacaan}

Buku cerita adalah bahan yang menyokong perkembangan emosi kanak-kanak SDH. Mereka akan mempelajari nilai dan budaya melalui sesebuah cerita. Mereka juga belajar emosi simpati dan empati untuk sesuatu perkara. Melalui pembacaan juga, kanak-kanak mudah menerima maklumat baharu. Buku cerita atau bahan bacaan perlu mengandungi banyak nilai budaya yang positif iaitu boleh dan sesuai diikuti oleh pembacanya. Peranan guru seharusnya mendedahkan rangsangan yang positif dan buku cerita yang menyeronokkan. Secara tidak langsung cara ini akan mendorong mereka untuk bekerjasama diantara satu sama yang lain. Apabila kanak-kanak ini dibimbing dalam menyelesaikan masalah mereka, reaksi positif dapat diperhatikan melalui raut wajah. Justeru itu pelbagai ekspresi yang dilahirkan seperti gembira, senyum, dan ketawa.

\section{KESIMPULAN}

Penggunaan kaedah pengajaran yang sesuai amat penting bagi memastikan ilmu atau maklumat yang ingin disampaikan kepada kanak-kanak SDH dapat diterima dengan baik dan memuaskan. Suasana pembelajaran di kawasan hospital adalah berbeza dengan suasana pembelajaran di sekolah-sekolah biasa dan hal ini mungkin memberikan tekanan kepada mereka. Penggunaan bahan sastera kaedah didik hibur yang diaplikasikan secara biblioterapi diharap dapat menghasilkan kesan positif terhadap perkembangan kanak-kanak SDH. Selain daripada itu, pengkaji juga berharap agar kualiti pengajaran dan pembelajaran bagi SDH dapat dipertingkatkan lagi supaya kanak-kanak yang diajar tidak ketinggalan daripada rakan-rakan mereka yang berada di sekolah konvensional. Sehubungan dengan itu aplikasi terapi biblio dapat membantu para guru SDH memupuk minat membaca di samping dapat memberikan motivasi secara psikologi untuk terus berjuang melawan penyakit yang dideritai oleh kanakkanak SDH melalui pembacaan bahan sastera. Di samping itu para guru SDH juga boleh memupuk dan menanamkan sifat kasih sayang serta saling hormat-menghormati di antara kanak-kanak dan ibu bapa mereka juga kepada para doktor yang merawat serta jururawat dan kakitangan hospital yang ada di sekeliling mereka.

\section{RUJUKAN}

Ahmad Mahdzan. (2005). Kaedah penyelidikan sosioekonomi. Kuala Lumpur: Dewan Bahasa dan Pustaka.

Amy Recob. (2008). Bibliotherapy, when kids need books: A guide for those in need of reassurance. New York: iUniverse, Inc.

Amir Hasan Dawi. (2006). Penteorian sosiologi dan pendidikan. Tanjung Malim: Quantum Books.

Ani Haji Omar dan Nor Shahirah. (2014). Sastera kanak-kanak untuk perkembangan diri yang seimbang. Tanjong Malim: Penerbit Mentari.

Affizal Ahmad. (2015). Buku cerita perangsang minda kanak-kanak. Kuala Lumpur: Dewan Bahasa dan Pustaka.

Azizi Yahaya. (2006). Menguasai penyelidikan dalam pendidikan: Teori, analisis \& interpretasi data. Kuala Lumpur: PTS Professional Publishing Sdn. Bhd.

Graziano, A. M. dan Raulin, M. L. (1996). Research methods: A process of inquiry, $3^{\text {rd }}$ Edition. New York: Addison Wesley Longman, Inc.

Halimah Mohamed Ali dan Mohamad Luthfi. (2013). Sastera dalam budaya dan media. Penang: Penerbit Universiti Sains Malaysia.

Hashim Awang. (2015). Kritikan sastera dalam teori, aplikasi dan tradisi. Selangor: PTS AKADEMIA.

Jean A Pardeck. (2014). Using books in clinical social work practice: A guide to bibliotherapy. New York: Routledge

Khadijah Hashim. (2008). Semut melancong ke Pulau Pinang. Ikan emas mangsa banjir. Selangor: 'K' Publishing Sdn. Bhd.

Khadijah Hashim. (2008). Itik dan buaya. Selangor: 'K' Publishing Sdn. Bhd. 
Khadijah Hashim. (2008). Sedap rumput enak lagi lobak. Selangor: 'K' Publishing Sdn. Bhd.

Khadijah Hashim. (2010). Ikan emas mangsa banjir. Selangor: 'K' Publishing Sdn. Bhd.

Khadijah Hashim. (2010). Angsa berjasa. Selangor. 'K' Publishing Sdn. Bhd.

Mahzan Arshad. (2003). Pendidikan literasi bahasa: Satu pendekatan bersepadu. Kuala Lumpur: Utusan Publications \& Distributors.

MD Sidin Ahmad Ishak. (2005). Perkembangan sastera kanak-kanak di Malaysia: Buku Melayu mencari nafas baru. Selangor: Cerdik Publications Sdn. Bhd.

Noraida Hassan ed. (2013). Rakan buku: Kaedah terapi biblio (Bibliotherapy) dengan pesakit pediatrik Hospital Universiti Sains Malaysia”. Kertas kerja dalam Seminar Kebangsaan Pustakawan Malaysia, Melaka, 25-27 Ogos 2013.

Rahman Shaari. (2002). Bimbingan istilah sastera. Kuala Lumpur: Utusan Publication \& Distributors Sdn. Bhd. Rubin, R. J. ed. (1978). Bibliotherapy sourcebook. London: Phoenix Oryx Press. SRN

Sohaimi Abdul Aziz. (1998). EQ membentuk kecerdasan emosi kanak-kanak melalui kesusasteraan kanak-kanak. Pulau Pinang: Penerbit Universiti Sains Malaysia

Wayne A. Wiegand and Donald G. Davis, Jr. (1994). Encyclopedia of library history. New York: Routledge. 